ARTICLE

https://doi.org/10.1038/s41467-020-20356-0

\title{
Important contributions of non-fossil fuel nitrogen oxides emissions
}

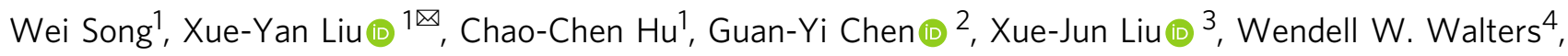
Greg Michalski ${ }^{5} \&$ Cong-Qiang Liu ${ }^{1}$

Since the industrial revolution, it has been assumed that fossil-fuel combustions dominate increasing nitrogen oxide $\left(\mathrm{NO}_{x}\right)$ emissions. However, it remains uncertain to the actual contribution of the non-fossil fuel $\mathrm{NO}_{x}$ to total $\mathrm{NO}_{x}$ emissions. Natural $\mathrm{N}$ isotopes of $\mathrm{NO}_{3}{ }^{-}$in precipitation ( $\delta^{15} \mathrm{~N}_{\mathrm{w}-\mathrm{NO}_{3}-}$ ) have been widely employed for tracing atmospheric $\mathrm{NO}_{\mathrm{x}}$ sources. Here, we compiled global $\delta^{15} \mathrm{~N}_{\mathrm{w}-\mathrm{NO} 3-}$ observations to evaluate the relative importance of fossil and non-fossil fuel $\mathrm{NO}_{\mathrm{x}}$ emissions. We found that regional differences in human activities directly influenced spatial-temporal patterns of $\delta^{15} \mathrm{~N}_{\mathrm{w}-\mathrm{NO} 3-}$ variations. Further, isotope mass-balance and bottom-up calculations suggest that the non-fossil fuel $\mathrm{NO}_{x}$ accounts for $55 \pm 7 \%$ of total $\mathrm{NO}_{\mathrm{x}}$ emissions, reaching up to $21.6 \pm 16.6 \mathrm{Mt} \mathrm{yr}^{-1}$ in East Asia,

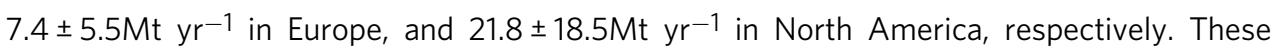
results reveal the importance of non-fossil fuel $\mathrm{NO}_{x}$ emissions and provide direct evidence for making strategies on mitigating atmospheric $\mathrm{NO}_{x}$ pollution.

\footnotetext{
${ }^{1}$ School of Earth System Science, Tianjin University, 300072 Tianjin, China. ${ }^{2}$ Georgia Tech Shenzhen Institute, Tianjin University, 518071 Shenzhen, China. ${ }^{3}$ College of Resources and Environmental Sciences, China Agricultural University, 100193 Beijing, China. ${ }^{4}$ Institute at Brown for Environment and Society, Brown University, 85 Waterman St, Providence, RI 02912, USA. ${ }^{5}$ Department of Earth, Atmospheric, and Planetary Sciences, Purdue University, 550 Stadium Mall Drive, West Lafayette, IN 47907, USA. ${ }^{\circledR}$ email: liuxueyan@tju.edu.cn
} 
O ver past decades, both concentrations and deposition fluxes of nitrogen oxides $\left(\mathrm{NO}_{x}\right)$, nitric acid $\left(\mathrm{HNO}_{3}\right)$, and nitrate $\left(\mathrm{NO}_{3}{ }^{-}\right)$in the atmosphere have been remarkably elevated in many regions of the world ${ }^{1-4}$. This has caused negative effects on the environmental quality (e.g., haze, eutrophication), human health (e.g., respiratory and cardiovascular diseases, acute bronchitis), and the structure and functions of ecosystems (e.g., soil acidification, biodiversity losses) ${ }^{5,6}$. Gaseous $\mathrm{NO}_{x}$, the sum of $\mathrm{N}$ oxide $(\mathrm{NO})$ and $\mathrm{N}$ dioxide $\left(\mathrm{NO}_{2}\right)$, is the precursor of atmospherically deposited $\mathrm{NO}_{3}-7,8$ and mainly emitted from fossil fuel combustion (primarily via coal combustion and vehicle exhausts) and non-fossil fuel sources including biomass burning, microbial $\mathrm{N}$ cycles in soils and animal wastes? Accurate differentiation of $\mathrm{NO}_{x}$ emissions from fossil-fuel and non-fossil emission sectors is pivotal for regulatory action to mitigate emissions, budget $\mathrm{NO}_{3}{ }^{-}$deposition fluxes, and model ecological and climatic effects of atmospheric $\mathrm{NO}_{3}{ }^{-}$loading.

It is feasible to estimate fossil fuel $\mathrm{NO}_{x}$ emissions according to known consumption amounts of fossil fuels and their $\mathrm{NO}_{x}$ emission factors ${ }^{10-12}$. More often, fossil fuel $\mathrm{NO}_{x}$ emissions in many countries have been recorded in national statistics yearbooks and emission inventories ${ }^{2,12-15}$. Since the 1990s, fossil fuel $\mathrm{NO}_{x}$ emissions have accounted for $95 \%$ of global $\mathrm{NO}_{x}$ emissions ${ }^{11}, 90 \%$ of $\mathrm{NO}_{x}$ emissions in Europe ${ }^{2}, 88 \%$ of $\mathrm{NO}_{x}$ emissions in East Asia ${ }^{10}$, and $96 \%$ of $\mathrm{NO}_{x}$ emissions in North America ${ }^{14,15}$. In contrast, the importance and amount of non-fossil fuel $\mathrm{NO}_{x}$ emissions remain unclear due to the difficulties in obtaining their emission factors and amounts. Particularly, it is almost impossible to budget $\mathrm{NO}_{x}$ emission amounts from diverse biomass burnings and microbial $\mathrm{N}$ cycles that occur in different solid- and liquidphase substrates ${ }^{16-18}$. In many cases, data of emission factors and estimates of emission budgets were rather incomplete and even unrecorded for non-fossil fuel $\mathrm{NO}_{x}$.

However, according to the simulation results of atmospheric chemical transport and terrestrial ecosystem models, biomass burning and soil emissions account for about $20 \%$ and $22 \%$ of global $\mathrm{NO}_{x}$ emissions, respectively ${ }^{19-21}$. The combination of a bottom-up spatial model and top-down airborne observations of atmospheric $\mathrm{NO}_{x}$ concentrations through satellite imagery pointed to a significant and overlooked $\mathrm{NO}_{x}$ emission from cropland soils, which constitutes $20-51 \%$ of the total $\mathrm{NO}_{x}$ budget at the regional scale 22 . Recently, natural stable $\mathrm{N}$ isotopes (expressed as $\delta^{15} \mathrm{~N}, \delta^{15} \mathrm{~N}=\left({ }^{15} \mathrm{~N} /{ }^{14} \mathrm{~N}\right)_{\text {sample }} /\left({ }^{15} \mathrm{~N} /{ }^{14} \mathrm{~N}\right)$ standard -1 , where atmospheric $\mathrm{N}_{2}$ is used as the internationally recognized $\mathrm{N}$ isotopic standard) have been widely employed for tracking $\mathrm{NO}_{x}$ emissions ${ }^{7,23-25}$. Isotopic investigations have demonstrated that $\mathrm{NO}_{x}$ from biomass burning and microbial $\mathrm{N}$ cycle may account for more than $40 \%$ of $\mathrm{NO}_{3}{ }^{-}$in particulates and precipitation collected in urban sites of China ${ }^{26,27}$. In summary, we argue that the importance of non-fossil fuel $\mathrm{NO}_{x}$ is still an open question.

$\mathrm{NO}$ is the most initial form of fossil fuel and non-fossil fuel $\mathrm{NO}_{x}$ emissions, but $\mathrm{NO}$ is normally insoluble and will be rapidly oxidized to $\mathrm{NO}_{2}$ in the atmosphere, forming the photochemical $\mathrm{NO}_{x}$ cycle ${ }^{28}$. The mixing of fossil fuel and non-fossil fuel $\mathrm{NO}_{x}$ emissions forms the initial $\mathrm{NO}_{x}$ pool in the atmosphere $\left(\mathrm{i}-\mathrm{NO}_{x}\right)$ (Supplementary Fig. 1). In reality, it is extremely difficult if not impossible to directly measure the $\mathrm{i}-\mathrm{NO}_{x}$ pool due to instantaneous emissions and oxidations. However, the $\delta^{15} \mathrm{~N}$ of the $\mathrm{i}-\mathrm{NO}_{x}$ (i.e., $\delta^{15} \mathrm{~N}_{\mathrm{i}-\mathrm{NO} x}$ ) is a straightforward parameter to integrate initial $\mathrm{NO}_{x}$ emissions and thus to differentiate relative contributions between fossil and non-fossil fuel $\mathrm{NO}_{x}$ emissions ${ }^{26,27}$. In the atmosphere, the $\mathrm{i}-\mathrm{NO}_{x}$ is partially oxidized to $\mathrm{HNO}_{3}$ and particulate $\mathrm{NO}_{3}{ }^{-}\left(\mathrm{p}-\mathrm{NO}_{3}{ }^{-}\right)$(Supplementary Fig. 1), during which $\mathrm{N}$ isotopic fractionations ${ }^{29,30}$ lead to substantial $\delta^{15} \mathrm{~N}$ differences between ambient $\mathrm{NO}_{x}, \mathrm{HNO}_{3}$, and $\mathrm{p}-\mathrm{NO}_{3}-$. Because of the difficulty in constraining $\delta^{15} \mathrm{~N}$ differences among these species, it remains a big challenge to evaluate $\mathrm{i}-\mathrm{NO}_{x}$ sources based on $\delta^{15} \mathrm{~N}$ signatures of ambient $\mathrm{NO}_{x}, \mathrm{HNO}_{3}$, and $\mathrm{p}-\mathrm{NO}_{3}{ }^{-}$. However, precipitation can scavenge both the ambient $\mathrm{NO}_{2}$ and the oxidized $\mathrm{NO}_{2}$ (i.e., $\mathrm{HNO}_{3}$ and $\mathrm{p}-\mathrm{NO}_{3}{ }^{-}$) (Supplementary Fig. 1) ${ }^{31}$. Therefore, we can reconstruct the corresponding $\delta^{15} \mathrm{~N}_{\mathrm{i}-\mathrm{NO} x}$ values of the observed $\delta^{15} \mathrm{~N}_{\mathrm{w}-\mathrm{NO} 3-}$ values (Supplementary Figs. 1, 2). Assuming that the estimated $\delta^{15} \mathrm{~N}_{\mathrm{i}-\mathrm{NO} x}$ value represents and integrates the emission $\delta^{15} \mathrm{~N}_{\mathrm{i}-\mathrm{NO} x}$ value, we can differentiate relative contributions between fossil fuel and non-fossil fuel $\mathrm{NO}_{x}$ emissions $^{7,24,32}$.

Based on the above isotope theory, the $\delta^{15} \mathrm{~N}_{\mathrm{i}-\mathrm{NO} x}$ value can be estimated by the following equation (Eq. (1)):

$$
\begin{aligned}
\delta^{15} \mathrm{~N}_{\mathrm{i}-\mathrm{NOx}} & \\
= & \left(\delta^{15} \mathrm{~N}_{\mathrm{NO}} \times \mathrm{C}_{\mathrm{NO} 2} / f_{\mathrm{NO} 2}+\delta^{15} \mathrm{~N}_{\mathrm{HNO} 3} \times \mathrm{C}_{\mathrm{HNO} 3}+\delta^{15} N_{\mathrm{p}-\mathrm{NO} 3-} \times \mathrm{C}_{\mathrm{p}-\mathrm{NO} 3-}\right) / \\
& \left(\mathrm{C}_{\mathrm{NO} 2} / f_{\mathrm{NO} 2}+\mathrm{C}_{\mathrm{HNO} 3}+\mathrm{C}_{\mathrm{p}-\mathrm{NO} 3-}\right),
\end{aligned}
$$

where $\mathrm{C}_{\mathrm{NO} 2}, \mathrm{C}_{\mathrm{HNO}}$, and $\mathrm{C}_{\mathrm{p}-\mathrm{NO} 3}$ - are concentrations of ambient $\mathrm{NO}_{2}, \mathrm{HNO}_{3}$, and $\mathrm{p}-\mathrm{NO}_{3}-$ in the atmosphere, respectively. $f_{\mathrm{NO} 2}$ is the fraction of $\mathrm{NO}_{2}$ in $\mathrm{NO}_{x} . \delta^{15} \mathrm{~N}_{\mathrm{NO} x}, \delta^{15} \mathrm{~N}_{\mathrm{HNO} 3}$, and $\delta^{15} \mathrm{~N}_{\mathrm{p}-\mathrm{NO} 3}$ are $\delta^{15} \mathrm{~N}$ values of $\mathrm{NO}_{x}, \mathrm{HNO}_{3}$, and $\mathrm{p}-\mathrm{NO}_{3}{ }^{-}$in the atmosphere, respectively. The values used for $\mathrm{C}_{\mathrm{NO} 2}, \mathrm{C}_{\mathrm{HNO} 3}, \mathrm{C}_{\mathrm{p}-\mathrm{NO} 3-}, f_{\mathrm{NO} 2}$, $\delta^{15} \mathrm{~N}_{\mathrm{NO} x}, \delta^{15} \mathrm{~N}_{\mathrm{HNO} 3}$, and $\delta^{15} \mathrm{~N}_{\mathrm{p}-\mathrm{NO} 3 \text { - are listed in Supplementary }}$ Table 1 . Due to the limited availability of $f_{\mathrm{NO} 2}$ and $\delta^{15} \mathrm{~N}_{\mathrm{NO} x}$ values, global mean values were used in our calculations $\left(f_{\mathrm{NO} 2}=64 \pm 10 \%\right.$, and $\delta^{15} \mathrm{~N}_{\mathrm{NO} x}=-7.7 \pm 2.9 \%$ ) (Supplementary Table 1).

To investigate the importance of non-fossil fuel $\mathrm{NO}_{x}$ emissions to total $\mathrm{NO}_{x}$ emissions, we compiled available $\delta^{15} \mathrm{~N}$ values of $\mathrm{NO}_{3}{ }^{-}$in precipitation (denoted as $\delta^{15} \mathrm{~N}_{\mathrm{w}-\mathrm{NO} 3-}$ hereafter) at urban and non-urban sites of East Asia, Europe, and North America (detailed in "Methods") (Fig. 1). Both the concentrations and $\delta^{15} \mathrm{~N}$ values of ambient $\mathrm{NO}_{x}, \mathrm{HNO}_{3}$, and $\mathrm{p}-\mathrm{NO}_{3}{ }^{-}$were used to constrain the $\delta^{15} \mathrm{~N}$ values of the initial mixture of fossil fuel and nonfossil fuel $\mathrm{NO}_{x}$ in the atmosphere (denoted as $\delta^{15} \mathrm{~N}_{\mathrm{i}-\mathrm{NO} x}$, detailed in "Methods") (Supplementary Fig. 1). Then we evaluated the differences between $\delta^{15} \mathrm{~N}_{\mathrm{w}-\mathrm{NO} \text { - }}$ and $\delta^{15} \mathrm{~N}_{\mathrm{i}-\mathrm{NO} x}$ values (denoted as ${ }^{15} \Delta_{\mathrm{i}-\mathrm{NO} x \rightarrow \mathrm{W}-\mathrm{NO} 3-},{ }^{15} \Delta_{\mathrm{i}-\mathrm{NO} x \rightarrow \mathrm{w}-\mathrm{NO} 3-}=\delta^{15} \mathrm{~N}_{\mathrm{w}-\mathrm{NO} 3-}-\delta^{15} \mathrm{~N}_{\mathrm{i}-\mathrm{NO} x}$, detailed in "Methods"). By combining the ${ }^{15} \Delta_{\mathrm{i}-\mathrm{NOx} \rightarrow \mathrm{w}-\mathrm{NO} 3-\text { values }}$ (Supplementary Fig. 2), the observed $\delta^{15} \mathrm{~N}_{\mathrm{w}-\mathrm{NO} 3-}$ values, and $\delta^{15} \mathrm{~N}$ values of dominant fossil fuel and non-fossil fuel $\mathrm{NO}_{x}$ sources (Supplementary Figs. 3, 13), we calculated relative contributions of dominant fossil fuel and non-fossil fuel $\mathrm{NO}_{x}$ by using a statistical isotope mass-balance model.

\section{Results and discussion}

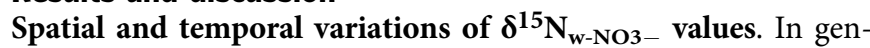
eral, East Asia has significantly higher $\delta^{15} \mathrm{~N}_{\mathrm{w}-\mathrm{NO} 3}$ - values $(1.7 \pm$ $5.4 \%$ at urban sites and $0.3 \pm 3.1 \%$ at non-urban sites) than Europe $(0.8 \pm 2.6 \%$ and $-1.5 \pm 2.6 \%$, respectively) and North America $(-0.5 \pm 1.9 \%$ and $-1.9 \pm 2.1 \%$, respectively) (Fig. 2). This result reflects more influences of the ${ }^{15} \mathrm{~N}$-enriched $\mathrm{NO}_{x}$ from coal combustion ( $\delta^{15} \mathrm{~N}=13.7 \pm 3.9 \%$; Supplementary Fig. 3$)$ in East Asia than in the other two study regions. Supportively, the amount of coal consumption in East Asia accounted for about $55 \%$ of the world's total amount during 1965-2015, even up to about 64\% during 1990-2015 (Supplementary Fig. 4a). Moreover, the $\mathrm{NO}_{x}$ from coal combustion has influenced $\delta^{15} \mathrm{~N}_{\mathrm{w}-\mathrm{NO} 3-}$ signatures of both urban and non-urban areas in East Asia, so that

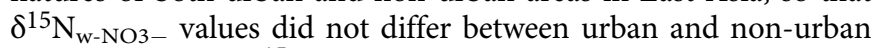
sites (Fig. 2). The $\delta^{15} \mathrm{~N}_{\mathrm{w}-\mathrm{NO} 3-\text { values are lower at non-urban sites }}$ than at urban sites in Europe and North America (Fig. 2), reflecting more influences of the ${ }^{15} \mathrm{~N}$-depleted $\mathrm{NO}_{x}$ from microbial $\mathrm{N}$ cycle $\left(\delta^{15} \mathrm{~N}=-30.2 \pm 6.7 \%\right.$; Supplementary Fig. 3$)$ at non-urban sites of these two regions than that of East Asia. 

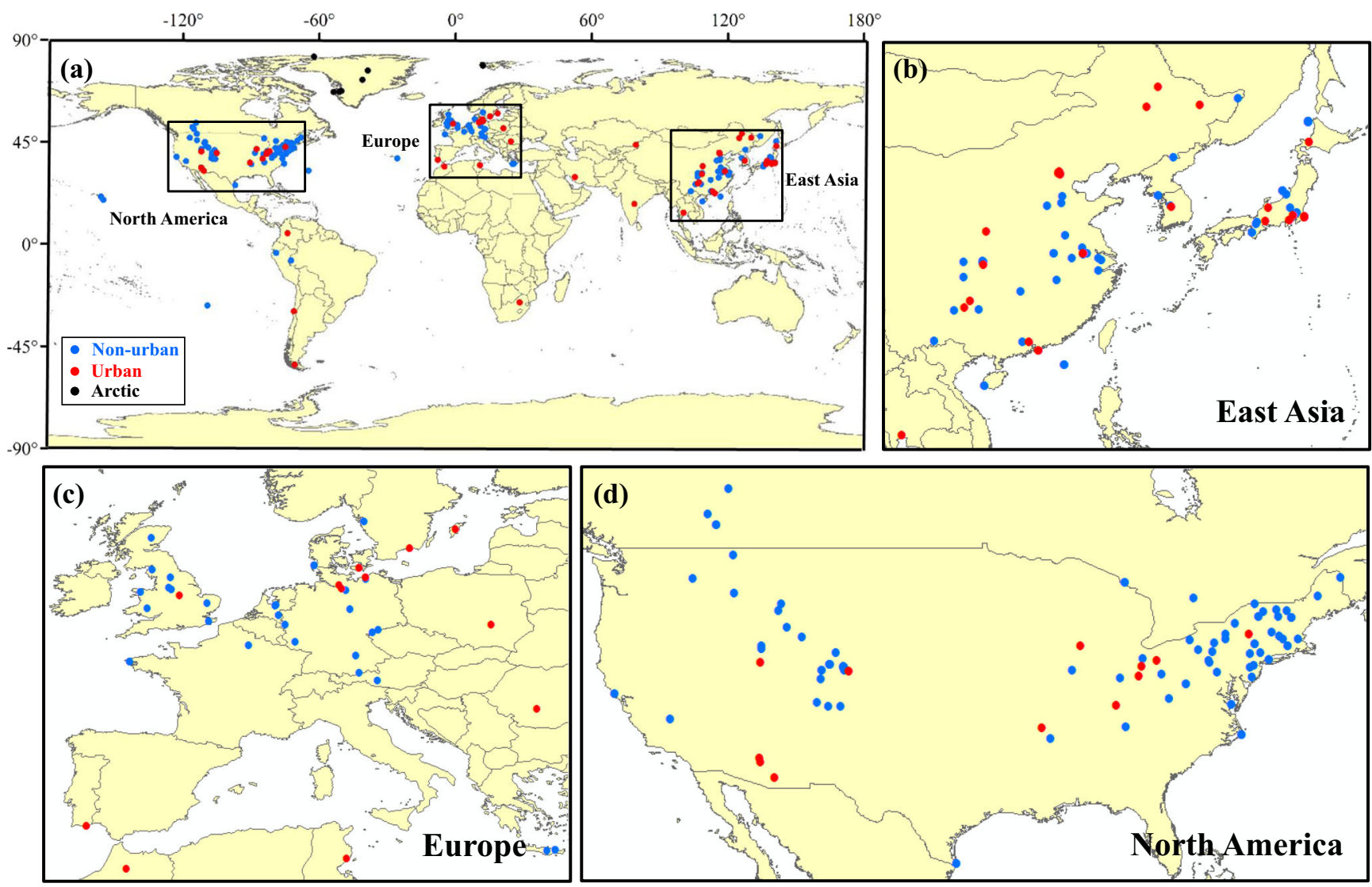

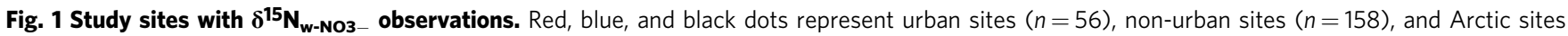
$(n=8)$, respectively.

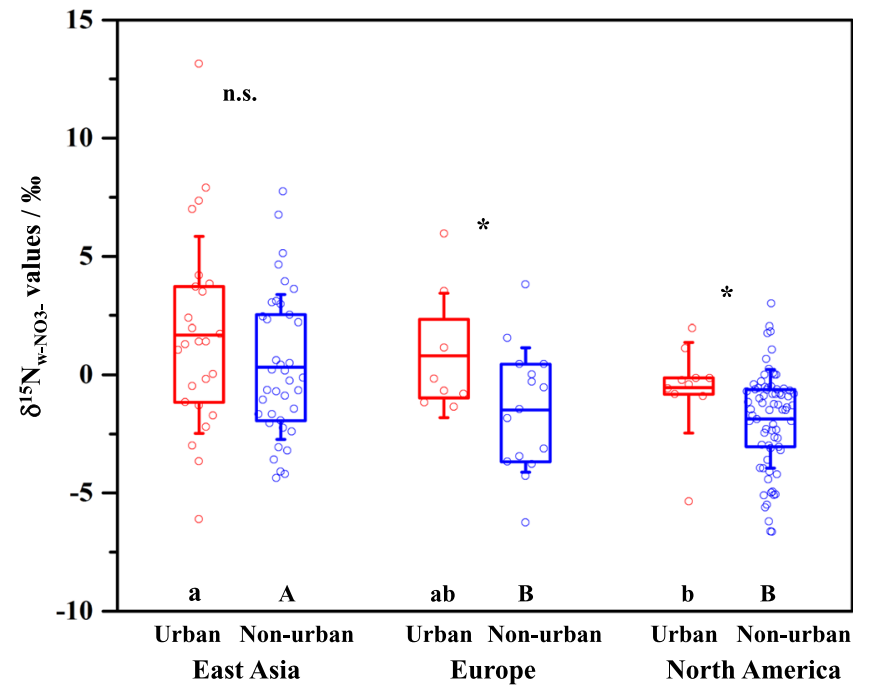

Fig. $2 \delta^{15} \mathrm{~N}_{\mathrm{w}-\mathrm{NO} \text { - }}$ values at urban and non-urban sites of East Asia $(n=25$ and $n=38$, respectively), Europe $(n=8$ and $n=15$, respectively), and North America ( $n=10$ and $n=73$, respectively). Dots show mean values of replicate measurements at each site. The box encompasses the 25th-75th percentiles, whiskers, and line in each box are the SD and mean values, respectively. The symbol of * indicates differences between urban and non-urban sites. n.s.: not significant. Different letters indicate differences among East Asia, Europe, and North America. The significance level was set at $P<0.1$.
The three study regions exhibit different temporal variations in $\delta^{15} \mathrm{~N}_{\mathrm{w}-\mathrm{NO} 3-}$ values (Fig. 3). In East Asia, $\delta^{15} \mathrm{~N}_{\mathrm{w}-\mathrm{NO} 3-\text { values }}$ increased at both urban and non-urban sites from 2000 to 2007 and then decreased very slowly (Fig. 3). This trend reflects the controlling strategies of $\mathrm{NO}_{x}$ emissions from coal combustion in East Asia, particularly in China. During 2000-2007, the amount of coal consumption in China accounts for $89 \pm 2 \%$ of the total amount in East Asia (Supplementary Fig. 4b). As a turning point, China started to implement mitigation measures for $\mathrm{NO}_{x}$ from coal combustion in 2007, i.e., the policy of "replacing small generation units with large ones" for coal power plants ${ }^{33,34}$. Since 2008 , a largescale flue gas denitrification technology has been widely utilized in coal-fired power plants of China to reduce the $\mathrm{NO}_{x}$ emission from

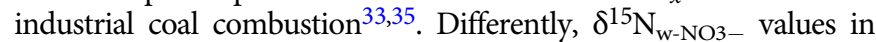
Europe decreased from 2002 to 2017 (Fig. 3) in response to a decrease in $\mathrm{NO}_{x}$ emissions from the coal combustion because the coal consumption in Europe has reduced by 20\% from 2002 to 2017 (Supplementary Fig. 4a). Although there was a significant decrease in the amount of coal combustion (by 34\%) in North America during 2000-2017 (Supplementary Fig. 4a), corresponding $\delta^{15} \mathrm{~N}_{\mathrm{w}-\mathrm{NO} 3-}$ values were relatively consistent (Fig. 3 ). This pattern reflects the $\mathrm{NO}_{x}$ emission reduction technology used in power plants because the technology can raise $\delta^{15} \mathrm{~N}$ values of $\mathrm{NO}_{x}$ emitted ${ }^{36}$.

Importance of non-fossil fuel $\mathrm{NO}_{x}$ emissions. Results from the Stable Isotope Analysis in R (the SIAR model; detailed in "Methods") showed that variations in relative contributions of $\mathrm{NO}_{x}$ from coal combustion are the main cause of different temporal patterns of regional $\delta^{15} \mathrm{~N}_{\mathrm{w}-\mathrm{NO} 3-}$ variations. (Supplementary Figs. 5-8). 

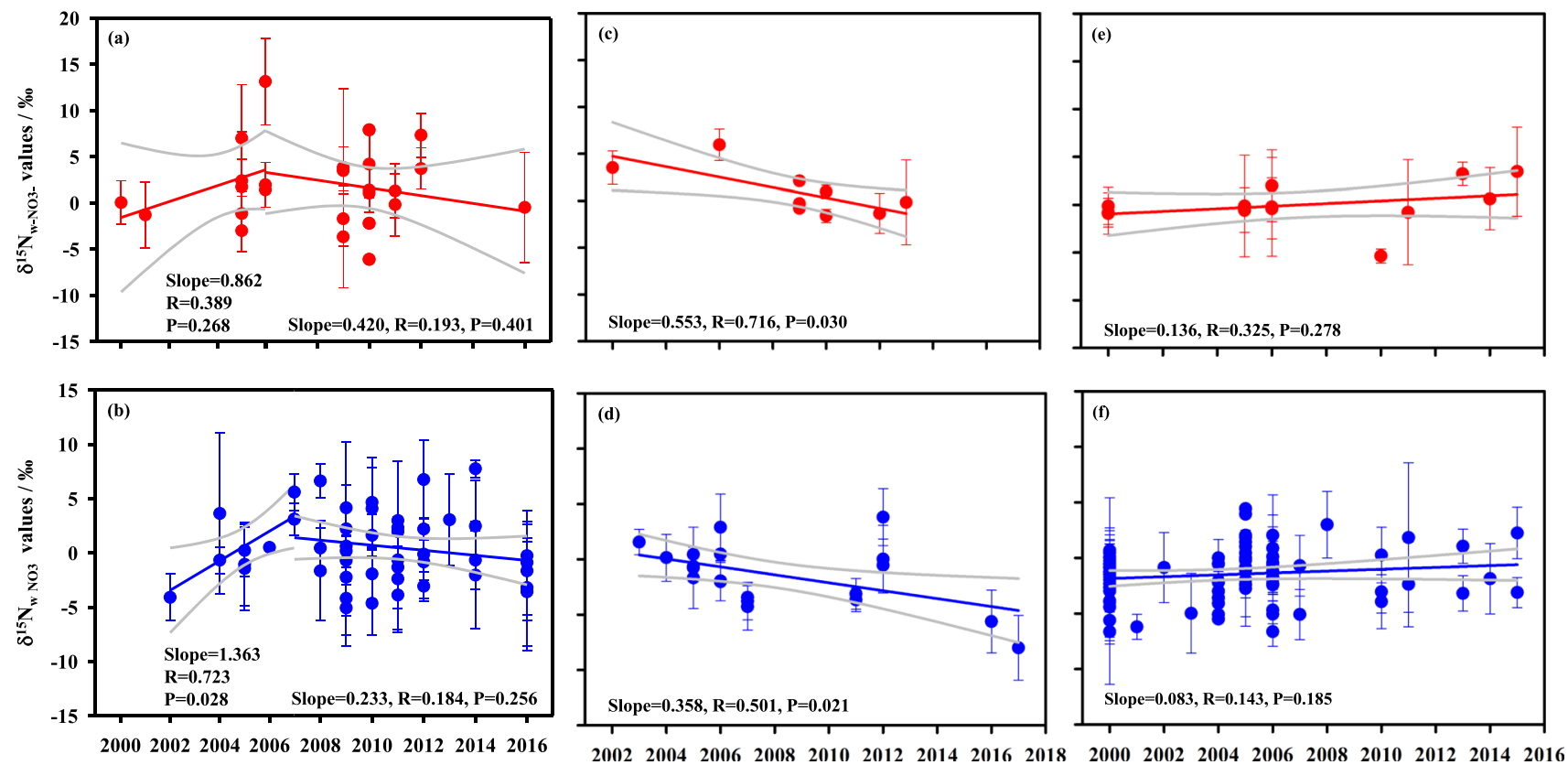

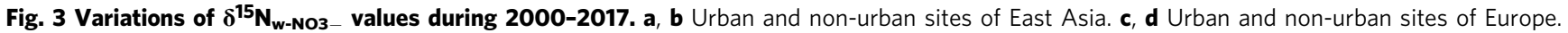
e, $\mathbf{f}$ Urban and non-urban sites of North America. Mean values of replicate measurements at each site in each year are shown. The gray lines are the $95 \%$ confidence intervals.

However, relative contributions of non-fossil fuel $\mathrm{NO}_{x}$ emissions average $49 \pm 11 \%$ at urban sites and $69 \pm 13 \%$ at non-urban sites for all three study regions (Supplementary Fig. 9). By integrating urban and non-urban sites in each region, we found that relative contributions of non-fossil fuel $\mathrm{NO}_{x}$ average $57 \pm 13 \%$ in East Asia, $54 \pm$ $13 \%$ in Europe, and $53 \pm 13 \%$ in North America (Fig. 4a, Supplementary Fig. 9). Based on mean annual emission amounts of $\mathrm{NO}_{x}$ from coal combustion and vehicle exhausts (Fig. 4b, Supplementary Fig. 10) and their annual mean relative contributions to total $\mathrm{NO}_{x}$ emissions (Fig. 4a), the mean annual $\mathrm{NO}_{x}$ emissions are estimated (detailed in "Methods") at $37.9 \pm 16.4 \mathrm{Mt} \mathrm{yr}^{-1}$ in East Asia during 2000-2016, $13.7 \pm 5.6 \mathrm{Mt} \mathrm{yr}^{-1}$ in Europe during 2000-2017, and $41.1 \pm 18.8 \mathrm{Mt} \mathrm{yr}^{-1}$ in North America during 2000-2015, respectively (Fig. 4b). Then, non-fossil fuel $\mathrm{NO}_{x}$ emission has been determined at $21.6 \pm 16.6 \mathrm{Mt} \mathrm{yr}^{-1}$ in East Asia, $7.4 \pm 5.5 \mathrm{Mt} \mathrm{yr}^{-1}$ in Europe, and $21.8 \pm 18.5 \mathrm{Mt} \mathrm{yr}^{-1}$ in North America, respectively (Fig. $4 \mathrm{~b}$ ). These values for regional $\mathrm{NO}_{x}$ emissions are valuable because they have long been missing in budgeting $\mathrm{NO}_{x}$ deposition and modeling effects of atmospheric $\mathrm{NO}_{x}$ loading.

Although we have considered uncertainties, there are still a few factors that remain difficult to quantify in the current stage. First, not all $\mathrm{NO}_{x}$ emission sources have been considered in $\delta^{15} \mathrm{~N}$ observations, and other sources such as natural gases and oil fuel combustion might be important in a few sites. Second, data heterogeneities in time and space are also a source of uncertainty, as it is almost impossible to measure the parameters used in our calculations simultaneously. Furthermore, the SIAR model only provides possible distributions but not definitive solutions of relative contributions of multiple sources. Therefore, future efforts on constraining these uncertainties will improve natural isotope evidence on global $\mathrm{NO}_{x}$ emissions.

Remarks. Our study provides direct isotope evidence on that the changes in regional human activities have distinct influences on $\delta^{15} \mathrm{~N}$ signatures of deposited $\mathrm{NO}_{\mathrm{x}}$ to terrestrial environments.
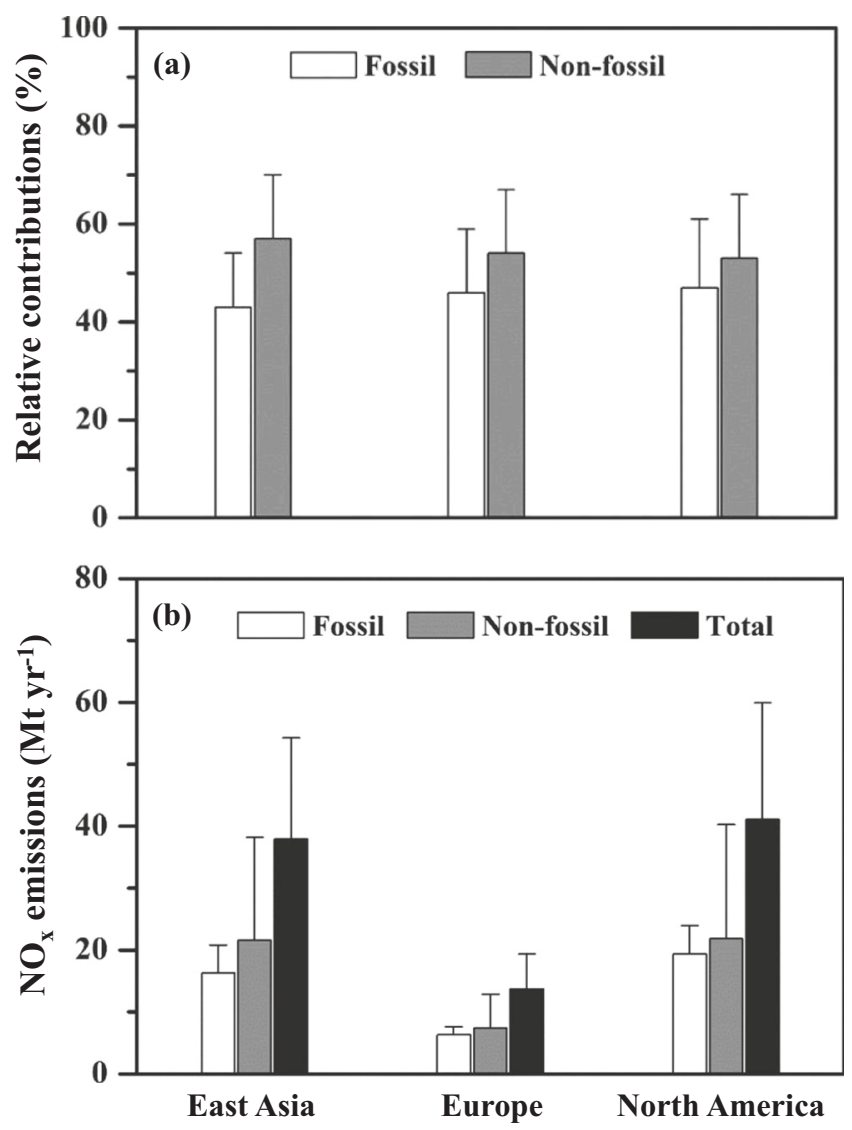

Fig. 4 Fossil and non-fossil fuel $\mathrm{NO}_{\mathrm{x}}$ emissions in East Asia, Europe, and North America. a Relative contributions. b Emission amounts. Mean \pm SD values are shown. 
The $\delta^{15} \mathrm{~N}_{\mathrm{w}-\mathrm{NO} 3-}$ values exhibit significant spatiotemporal changes, which can be used to trace anthropogenic $\mathrm{N}$ inputs and help us understand decadal $\delta^{15} \mathrm{~N}$ variations in materials of surface-earth systems, such as tree rings, sediments, and oceanic biota. Currently, environmental policies in many countries of the study regions mostly aim to mitigate more fossil fuel $\mathrm{NO}_{x}$ emissions via technology promotion and energy structure adjustment. However, our study shows that non-fossil fuel $\mathrm{NO}_{x}$ emission is equally as important as fossil fuel $\mathrm{NO}_{\mathrm{x}}$ emission, and it has long been underestimated. Accordingly, the control of nonfossil fuel $\mathrm{NO}_{x}$ emissions should be equally considered in the mitigation of $\mathrm{NO}_{x}$ pollution. Moreover, regional $\mathrm{NO}_{x}$ emissions newly constrained in this study are useful for budgeting $\mathrm{NO}_{3}{ }^{-}$ deposition fluxes and modeling ecological and climatic effects of atmospheric $\mathrm{NO}_{3}{ }^{-}$loading.

\section{Methods}

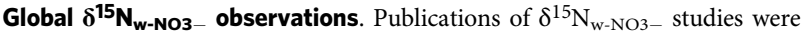
obtained through the databases of the Web of Science (http://isiknowledge.com), Google Scholar (http://scholar.google.com.hk), and Baidu Scholar (http://xueshu. baidu.com) by searching keywords of "nitrogen isotope", "nitrate", "rainfall", and "precipitation". By the end of December 2018, a total of 128 publications were available (Supplementary Text 1), spanning the sampling time of 1956-2017 (Supplementary Fig. 11). We extracted $\delta^{15} \mathrm{~N}_{\mathrm{w}-\mathrm{NO} 3-}$ values of individual precipitation samples by using the software of Web Plot Digitizer ${ }^{37}$.

There are totally 3483 individual $\delta^{15} \mathrm{~N}_{\mathrm{w}-\mathrm{NO} 3-}$ data and 222 sampling sites when multiple observations in different sampling years at the same site were counted once only (Fig. 1). There are 56 urban sites, 158 non-urban sites, and eight arctic sites (Fig. 1), in which non-urban sites are mainly situated in rural, mountain, forest, and lake areas. Due to the sparsity of available data before 2000 (Supplementary Fig. 11), we analyzed $\delta^{15} \mathrm{~N}_{\mathrm{w}-\mathrm{NO} 3-}$ data at major urban and nonurban sites in East Asia, Europe, and North America during 2000-2017 to ensure a better site representation and to reduce the uncertainty caused by inconsistency in sampling time (Fig. 1). To describe spatial differences in $\delta^{15} \mathrm{~N}_{\mathrm{w}-\mathrm{NO} 3-}$ values between urban and non-urban sites among three regions (totally 214 sites), only site-based mean values during the period of 2000-2017 (totally 169 sites) were used (detailed in Fig. 2). To describe temporal variations of $\delta^{15} \mathrm{~N}_{\mathrm{w}-\mathrm{NO} 3-}$ values in urban and non-urban areas of each region, respectively (Fig. 3), we counted observation sites by different sampling years, given that $\delta^{15} \mathrm{~N}_{\mathrm{w}-\mathrm{NO} 3-}$ observations at few sites have been conducted in different sampling years. In this way, there were a total of 206 sites during 2000-2017 (detailed in Fig. 3). In addition, 35\%, 29\%, and 36\% of

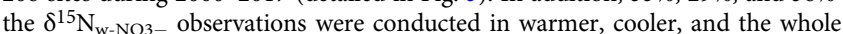
year, respectively. The seasonal effects of $\mathrm{NO}_{x}$ emissions may not substantially influence the patterns of regional $\delta^{15} \mathrm{~N}_{\mathrm{w}-\mathrm{NO} 3-}$ variations.

Differences between $\boldsymbol{\delta}^{\mathbf{1 5}} \mathbf{N}_{\mathrm{w}-\mathrm{NO} \text { - }}$ and $\boldsymbol{\delta}^{\mathbf{1 5}} \mathbf{N}_{\mathrm{i} \text {-NOx }}$ values. NO is normally insoluble in water, and $\mathrm{w}-\mathrm{NO}_{3}{ }^{-}$is scavenged only from the ambient $\mathrm{NO}_{2}$ and the oxidized $\mathrm{NO}_{x}$ (i.e., $\mathrm{HNO}_{3}$ and $\mathrm{p}-\mathrm{NO}_{3}{ }^{-}$) (Supplementary Fig. 1) ) $^{32,38,39}$. Moreover, isotopic effects during the $\mathrm{NO}_{x}$ cycles lead to differences between $\delta^{15} \mathrm{~N}_{\mathrm{NO} x}$ and $\delta^{15} \mathrm{~N}_{\mathrm{NO} 2}$. Therefore, substantial differences exist between the $\delta^{15} \mathrm{~N}_{\mathrm{w}-\mathrm{NO} 3-}$ and $\delta^{15} \mathrm{~N}_{\mathrm{i}-\mathrm{NO} x}$ values in the atmosphere (hereafter denoted as ${ }^{15} \Delta_{\mathrm{i}-\mathrm{NO} x \rightarrow \mathrm{w}-\mathrm{NO} 3-}$ ). In this study, we calculated ${ }^{15} \Delta_{\mathrm{i}-\mathrm{NO} x \rightarrow \mathrm{w}-\mathrm{NO} 3-}$ values by using the following equation (Eq. (2)):

$$
{ }^{15} \Delta_{\mathrm{i}-\mathrm{NOx} \rightarrow \mathrm{w}-\mathrm{NO} 3-}=\delta^{15} \mathrm{~N}_{\mathrm{w}-\mathrm{NO} 3-}-\delta^{15} \mathrm{~N}_{\mathrm{i}-\mathrm{NOx}} .
$$

Combined Eq. (1) with Eq. (2), we get Eq. (3) to calculate the ${ }^{15} \Delta_{\mathrm{i}-\mathrm{NO} x \rightarrow \mathrm{w}-\mathrm{NO} 3-}$ values.

$$
\begin{aligned}
& { }^{15} \Delta_{\mathrm{i}-\mathrm{NO} \rightarrow \mathrm{w}-\mathrm{NO} 3}=\delta^{15} \mathrm{~N}_{\mathrm{w}-\mathrm{NO} 3-} \\
& \quad-\left(\delta^{15} \mathrm{~N}_{\mathrm{NO}} \times \mathrm{C}_{\mathrm{NO} 2} / \mathrm{f}_{\mathrm{NO} 2}+\delta^{15} \mathrm{~N}_{\mathrm{HNO} 3} \times \mathrm{C}_{\mathrm{HNO} 3}+\delta^{15} \mathrm{~N}_{\mathrm{p}-\mathrm{NO} 3-} \times \mathrm{C}_{\mathrm{p}-\mathrm{NO} 3}\right) / \\
& \left(\mathrm{C}_{\mathrm{NO} 2} / f_{\mathrm{NO} 2}+\mathrm{C}_{\mathrm{HNO} 3}+\mathrm{C}_{\mathrm{p}-\mathrm{NO} 3-}\right) .
\end{aligned}
$$

To obtain more accurate ${ }^{15} \Delta_{\mathrm{i}-\mathrm{NO} x \rightarrow \mathrm{w}-\mathrm{NO} 3-}$ values, we estimated the ${ }^{15} \Delta_{\mathrm{i}-\mathrm{NO} x \rightarrow \mathrm{w}-}$ $\mathrm{NO}_{3}-$ values in two independent scenarios. In Scenario 1, mean values of global $\delta^{15} \mathrm{~N}_{\mathrm{NO} x}$ and $f_{\mathrm{NO} 2}$ values, simultaneously observed values of ambient $\mathrm{C}_{\mathrm{NO} 2}, \mathrm{C}_{\mathrm{HNO} 3}$, $\mathrm{C}_{\mathrm{p}-\mathrm{NO} 3-}, \delta^{15} \mathrm{~N}_{\mathrm{HNO} 3}, \delta^{15} \mathrm{~N}_{\mathrm{p}-\mathrm{NO} 3-}$, and $\delta^{15} \mathrm{~N}_{\mathrm{w}-\mathrm{NO} 3}$ - were used for the calculation in Eq. (3). In Scenario 2, non-synchronously observed values of ambient $f_{\mathrm{NO} 2}, \mathrm{C}_{\mathrm{NO} 2}$, $\mathrm{C}_{\mathrm{HNO} 3}, \mathrm{C}_{\mathrm{p}-\mathrm{NO} 3}, \delta^{15} \mathrm{~N}_{\mathrm{NO}}, \delta^{15} \mathrm{~N}_{\mathrm{HNO} 3}, \delta^{15} \mathrm{~N}_{\mathrm{p}-\mathrm{NO} 3}$, and $\delta^{15} \mathrm{~N}_{\mathrm{w}-\mathrm{NO} 3}$ - were used for the calculation in Eq. (3). The values and data sources of parameters used for estimating ambient ${ }^{15} \Delta_{\mathrm{i}-\mathrm{NO} x \rightarrow \mathrm{w}-\mathrm{NO} 3-}$ values are included in Supplementary Table 1. Because data of $f_{\mathrm{NO} 2}$ and $\delta^{15} \mathrm{~N}_{\mathrm{NO} x}$ are very sparse globally, we used global mean values and considered their SD values into the uncertainty analysis by the Monte Carlo method. Furthermore, because of no significant difference between ${ }^{15} \Delta_{\mathrm{i}}$ NOx $\rightarrow$ w-NO3- values obtained in Scenario $1(2.1 \pm 1.7 \%)$ and Scenario $2(5.7 \pm 3.2 \%)$ (Supplementary Fig. 2), we used a mean value of them (3.9 $\pm 1.8 \%$; Supplementary Fig. 2) in the calculations of source contributions (Eqs. (4) and (5)).
Contributions of dominant fossil fuel and non-fossil fuel $\mathrm{NO}_{\boldsymbol{x}}$ sources. Based on $\delta^{15} \mathrm{~N}_{\mathrm{w}-\mathrm{NO} 3-},{ }^{15} \Delta_{\mathrm{i}-\mathrm{NO} x \rightarrow \mathrm{W}-\mathrm{NO} 3-}$, and $\delta^{15} \mathrm{~N}$ values of $\mathrm{NO}_{x}$ sources, we estimated relative contributions of dominant fossil fuel and non-fossil fuel $\mathrm{NO}_{x}$ sources to total $\mathrm{NO}_{x}$ emissions by using the isotope mass-balance method. We considered coal combustion (denoted as $\mathrm{S} 1$ ) and vehicle exhausts (S2) as dominant fossil fuel $\mathrm{NO}_{\mathrm{x}}$ sources, and biomass burning (S3), and microbial $\mathrm{N}$ cycles (S4) as dominant non-fossil fuel $\mathrm{NO}_{x}$ sources. The major reasons include: (1) these four sources have been considered as dominant sources of total $\mathrm{NO}_{x}$ emissions in studies of both emission inventory and deposition modeling $2,9,11,13-15,19-21$; (2) they are also the dominant sources influencing $\delta^{15} \mathrm{~N}^{2}$ ariations of $\mathrm{NO}_{x}$ and $\mathrm{NO}_{3}{ }^{-}$in the atmosphere; 26,27 (3) their mean $\delta^{15} \mathrm{~N}$ values of $\mathrm{NO}_{x}$ emission sources differ significantly $(P<0.05$, Supplementary Fig. 3$)$ and therefore can be used to differentiate their relative contributions.

The S1-S4 are considered as dominant $\mathrm{NO}_{x}$ sources at urban sites but $\mathrm{S} 2$ cannot be considered as a dominant $\mathrm{NO}_{x}$ source at non-urban sites. First of all, studies of roadside $\mathrm{NO}_{x}$ emissions have evidenced that vehicle exhausts contribute little to atmospheric $\mathrm{NO}_{x}$ at non-urban sites due to limited amounts of long-range transport ${ }^{40-42}$. Statistical data also show $76 \%, 82 \%$, and $78 \%$ of vehicles distributed in urban areas of East Asia, North America, and Europe, respectively while their urban areas account for only $1.7 \%, 1.4 \%$, and $16.6 \%$ of total land area, respectively (Supplementary Tables 2, 3, Supplementary Fig. 12). Secondly, 76\% and 91\% of $\delta^{15} \mathrm{~N}_{\mathrm{w}-\mathrm{NO} 3-}$ values at urban and non-urban sites fall in the $\delta^{15} \mathrm{~N}$ range of $\mathrm{NO}_{x}$ from vehicle exhausts (Supplementary Figs. 3, 13). Consequently, when the $\mathrm{NO}_{x}$ from vehicle exhausts is considered into the calculations of relative contributions of different $\mathrm{NO}_{x}$ sources at non-urban sites, its contributions at non-urban sites $(25 \pm$ $12 \%)$ are similar to urban sites $(28 \pm 8 \%)$, which is unlikely. Besides, because mutual $\mathrm{NO}_{\mathrm{x}}$ transportations always occur between urban and non-urban areas, $\delta^{15} \mathrm{~N}$ values of $\mathrm{NO}_{3}{ }^{-}$in precipitation at a given urban or non-urban site integrate $\delta^{15} \mathrm{~N}$ values of $\mathrm{NO}_{x}$ from both local emissions and regional transportations. However, physical $\mathrm{NO}_{x}$ transportation might have no substantial isotope effects, and thus likely will not influence the site-specific evaluations of fossil and nonfossil fuel $\mathrm{NO}_{x}$ contributions.

According to isotope mass-balance theory, we calculated relative contributions of S1-S4 $\left(f_{\mathrm{S} 1}, f_{\mathrm{S} 2}, f_{\mathrm{S} 3}\right.$, and $f_{\mathrm{S} 4}$, respectively) at urban sites by using Eq. (4):

$$
\begin{aligned}
\delta^{15} \mathrm{~N}_{\mathrm{w}-\mathrm{NO} 3-}= & \left(f_{\mathrm{S} 1} \times \delta^{15} \mathrm{~N}_{\mathrm{S} 1}+f_{\mathrm{S} 2} \times \delta^{15} \mathrm{~N}_{\mathrm{S} 2}+f_{\mathrm{S} 3} \times \delta^{15} \mathrm{~N}_{\mathrm{S} 3}+f_{\mathrm{S} 4} \times \delta^{15} \mathrm{~N}_{\mathrm{S} 4}\right) \\
& +{ }^{15} \Delta_{\mathrm{i}-\mathrm{NOX} \rightarrow \mathrm{w}-\mathrm{NO} 3-},
\end{aligned}
$$

where we assumed that $f_{\mathrm{S} 1}+f_{\mathrm{S} 2}+f_{\mathrm{S} 3}+f_{\mathrm{S} 4}=1$.

Then, we calculated their relative contributions at non-urban sites by Eq. (5):

$$
\begin{aligned}
\delta^{15} \mathrm{~N}_{\mathrm{w}-\mathrm{NO} 3-}= & \left(f_{\mathrm{S} 1} \times \delta^{15} \mathrm{~N}_{\mathrm{S} 1}+f_{\mathrm{S} 3} \times \delta^{15} \mathrm{~N}_{\mathrm{S} 3}+f_{\mathrm{S} 4} \times \delta^{15} \mathrm{~N}_{\mathrm{S} 4}\right) \\
& +{ }^{15} \Delta_{\mathrm{i}-\mathrm{NOX} \rightarrow \mathrm{w}-\mathrm{NO} 3-},
\end{aligned}
$$

where we assumed that $f_{\mathrm{S} 1}+f_{\mathrm{S} 3}+f_{\mathrm{S} 4}=1 . \delta^{15} \mathrm{~N}_{\mathrm{S} 1}, \delta^{15} \mathrm{~N}_{\mathrm{S} 2}, \delta^{15} \mathrm{~N}_{\mathrm{S} 3}$, and $\delta^{15} \mathrm{~N}_{\mathrm{S} 4}$ represent $\delta^{15} \mathrm{~N}$ values of $\mathrm{NO}_{x}$ from coal combustion (S1), vehicle exhausts (S2), biomass burning (S3), and microbial $\mathrm{N}$ cycles (S4), respectively (Supplementary Fig. 3).

The $f_{\mathrm{S} 1}, f_{\mathrm{S} 2}, f_{\mathrm{S} 3}$, and $f_{\mathrm{S} 4}$ values were calculated by using a Bayesian isotope-mixing model (named Stable Isotope Analysis in R, SIAR). The SIAR model ${ }^{43}$ uses a Bayesian framework to establish a logical prior distribution based on Dirichlet distribution ${ }^{44}$ for estimating source contributions $\left(f_{\mathrm{S}_{1}}-f_{\mathrm{S} 4}\right)$. It has the potential to provide reliable estimations of source contributions because the isotope effect (i.e., ${ }^{15} \Delta_{\mathrm{i}-\mathrm{NO} x \rightarrow \mathrm{w}-\mathrm{NO} 3-}$ values in this study), the variability in $\delta^{15} \mathrm{~N}$ values of both sources (i.e., $\delta^{15} \mathrm{~N}$ values of $\mathrm{NO}_{x}$ from S1-S4 in this study), and the mixture (i.e., $\delta^{15} \mathrm{~N}_{\mathrm{w}-\mathrm{NO} 3-}$ values in this study) 45,46 are considered. The SIAR model has been widely used to quantify the relative contributions of multiple $\mathrm{NO}_{x}$ emission sources to $\mathrm{p}-\mathrm{NO}_{3}{ }^{-}$and $\mathrm{w}-\mathrm{NO}_{3}{ }^{-26,27,31,47}$. In each run of the SIAR model, the mean $\pm \mathrm{SD}$ of $\delta^{15} \mathrm{~N}_{\mathrm{NO} x}$ values (Supplementary Fig. 3), the mean \pm SD of ${ }^{15} \Delta_{\mathrm{w}-\mathrm{NO} 3 \rightarrow \mathrm{i}-\mathrm{NOx} x}$ values (Supplementary Fig. 2), and replicate $\delta^{15} \mathrm{~N}_{\mathrm{w}-\mathrm{NO} 3}$ - values at each urban or non-urban site in each sampling year (Fig. 3) were input into the model. In addition, the percentage data of each source $(n=10,000)$ output from each run of the SIAR model were used to calculate mean \pm SD values of corresponding source contributions (Supplementary Figs. 5-8).

We calculated the total contribution of each $\mathrm{NO}_{x}$ source in each region ( $F$; Eq. (6)) by using its annual mean relative contributions at urban and non-urban sites during 2000-2017 ( $n=28,9,13$ for urban sites and $n=47,21,88$ for non-urban sites in East Asia, Europe, and North America, respectively) $\left(f_{\text {urban }}\right.$ and $f_{\text {non-urban }}$, respectively; Supplementary Fig. 9) and annual mean proportions of urban and non-urban populations in the total population of each region during 2000-2017 ( $P_{\text {urban }}$ and $P_{\text {non- }}$ urban, respectively; Supplementary Fig. 14).

$$
F=f_{\text {urban }} \times P_{\text {urban }} \times f_{\text {non-urban }} \times P_{\text {non-urban }} .
$$

Then, we calculated annual mean relative contributions of dominant fossil fuel and non-fossil fuel $\mathrm{NO}_{x}$ sources in each region $\left(F_{\text {fossil }}\right.$ and $F_{\text {non-fossil }}$, respectively) by using Eq. (7) and Eq. (8), respectively.

$$
\begin{gathered}
F_{\text {fossil }}=F_{\mathrm{S} 1}+F_{\mathrm{S} 2}, \\
F_{\text {non-fossil }}=F_{\mathrm{S} 3}+F_{\mathrm{S} 4} .
\end{gathered}
$$

Finally, based on the annual mean amounts of fossil fuel $\mathrm{NO}_{x}$ emissions $\left(A_{\text {fossil }}\right)$ in 
East Asia during 2000-2010, in Europe during 2000-2015, and in North America during 2000-2016, respectively (Fig. 4b, Supplementary Fig. 10), the annual mean amounts of total $\mathrm{NO}_{x}$ emissions $\left(A_{\text {total }}\right)$ and non-fossil fuel $\mathrm{NO}_{x}$ emissions $\left(A_{\text {non- }}\right.$ fossil) in each region during 2000-2017 were calculated by using Eq. (9) and Eq. (10), respectively:

$$
\begin{gathered}
A_{\text {total }}=A_{\text {fossil }} / F_{\text {fossil }}, \\
A_{\text {non-fossil }}=A_{\text {total }}-A_{\text {fossil }} .
\end{gathered}
$$

We estimated the SD values of calculated values in Eqs. (6)-(10) and finally propagated into the uncertainties of the $A_{\text {non-fossil }}$ values by using the Monte Carlo method.

Statistical analyses. The one-way analyses of variance (Fig. 2) and Pearson correlation analyses (Fig. 3) were performed by using the Origin 2016 statistical package (OriginLab Corporation, USA) and SPSS 16.0 statistical package (SPSS Inc., Chicago, IL). Because of regionally limiting observation sites and inherently high variability of $\delta^{15} \mathrm{~N}_{\mathrm{w}-\mathrm{NO} 3-}$, spatial differences are significant only at the level of $P<0.1$ (Fig. 2). Mean values and standard deviation (SD) were reported.

\section{Data availability}

The data underlying the findings of this study are available in this article. Source data are provided with this paper.

Received: 3 April 2020; Accepted: 24 November 2020;

Published online: 11 January 2021

\section{References}

1. Galloway, J. N. et al. Nitrogen cycles: past, present, and future. Biogeochemistry 70, 153-226 (2004).

2. Sutton, M. A., Oenema, O., Erisman, J. W., Leip, A. \& Winiwarter, W. Too much of a good thing. Nature 472, 159-161 (2011).

3. Fowler, D. et al. The global nitrogen cycle in the twenty-first century. Phil. Trans. R. Soc. B. 368, 20130164 (2013).

4. Liu, X. J. et al. Enhanced nitrogen deposition over China. Nature 494, 459-462 (2013)

5. Clark, C. M. \& Tilman, D. Loss of plant species after chronic low-level nitrogen deposition to prairie grasslands. Nature 451, 712-715 (2008).

6. Guo, J. H. et al. Significant acidification in major Chinese croplands. Science 327, 1008-1010 (2010)

7. Morin, S. et al. Tracing the origin and fate of $\mathrm{NO}_{x}$ in the Arctic atmosphere using stable isotopes in nitrate. Science 322, 730-732 (2008).

8. Geng, L. et al. Nitrogen isotopes in ice core nitrate linked to anthropogenic atmospheric acidity change. Proc. Natl Acad. Sci. 111, 5808-5812 (2014).

9. Richter, A., Burrows, J. P., Nüß, K., Granier, C. \& Niemeier, U. Increase in tropospheric nitrogen dioxide over China observed from space. Nature $\mathbf{4 3 7}$ 129-132 (2005).

10. Ohara, T. et al. An Asian emission inventory of anthropogenic emission sources for the period 1980-2020. Atmos. Chem. Phys. 7, 4419-4444 (2007).

11. Anenberg, S. C. et al. Impacts and mitigation of excess diesel-related $\mathrm{NO}_{x}$ emissions in 11 major vehicle markets. Nature 545, 467-471 (2017).

12. Oberschelp, C., Pfister, S., Raptis, C. E. \& Hellweg, S. Global emission hotspots of coal power generation. Nature Sustain 2, 113-121 (2019).

13. National emission ceilings directive emissions data viewer 1990-2017. Data were downloaded from https://www.eea.europa.eu/data-and-maps/ dashboards/necd-directive-data-viewer-2.

14. Air pollutant emissions trends data. Data were downloaded from https://www. epa.gov/air-emissions-inventories/air-pollutant-emissions-trends-data.

15. Air pollutants emissions inventory online search. Data were downloaded from https://pollution-waste.canada.ca/air-emission-inventory.

16. Streets, D. G., Yarber, K. F., Woo, J. H. \& Carmichael, G. R. Biomass burning in Asia: annual and seasonal estimates and atmospheric emissions. Global Biogeochem. Cycles 17, 1099 (2003).

17. Castellanos, P., Boersma, K. F. \& Van, W. G. R. Satellite observations indicate substantial spatiotemporal variability in biomass burning NOx emission factors for South America. Atmos. Chem. Phys. 14, 3929-3943 (2014).

18. Oikawa, P. Y. et al. Unusually high soil nitrogen oxide emissions influence air quality in a high-temperature agricultural region. Nat. Commun. 6, 8753 (2015).

19. Martin, R. V. et al. Global inventory of nitrogen oxide emission constrained by space-based observations of NO2 columns. J. Geophys. Res. Atmos. 108, 1-12 (2003).

20. Jaeglé, L., Steinberger, L., Martin, R. V. \& Chance, K. Global partitioning of NOx sources using satellite observations: relative roles of fossil fuel combustion, biomass burning and soil emissions. Faraday Discuss 130, 407-423 (2005).

21. Jain, A. K., Tao, Z., Yang, X. \& Gillespie, C. Estimates of global biomass burning emissions for reactive greenhouse gases (CO, NMHCS, and NOx) and CO2. J. Geophys. Res. Atmos. 111, D06304 (2006).

22. Almaraz, M., Bai, E., Wang, C., Trousdell, J. \& Houlton, B. Z. Agriculture is a major source of NOx pollution in California. Sci. Adv. 4 , eaao3477 (2018).

23. Hoering, $\mathrm{T}$. The isotopic composition of the ammonia and the nitrate ion in rain. Geochim. Cosmochim. Acta 12, 97-102 (1957).

24. Kendall, C., Elliott, E. M. \& Wankel, S. D. in Stable Isotopes in Ecology and Environmental Science 2nd edn (eds Michener, R. M., Lajtha, K.) 375-449 (Blackwell, Oxford, 2007).

25. Gobel, A. R., Altieri, K. E., Peters, A. J., Hastings, M. G. \& Sigman, D. M. Insights into anthropogenic nitrogen deposition to the North Atlantic investigated using the isotopic composition of aerosol and rainwater nitrate. Geophys. Res. Lett. 40, 5977-5982 (2013).

26. Zong, Z. et al. First assessment of $\mathrm{NO}_{x}$ sources at a regional background site in North China using isotopic analysis linked with modeling. Environ. Sci. Technol. 51, 5923-5931 (2017).

27. Song, W. et al. Isotopic evaluation on relative contributions of major $\mathrm{NO}_{x}$ sources to nitrate of $\mathrm{PM}_{2.5}$ in Beijing. Environ. Pollut. 248, 183-190 (2019).

28. Ye, C. X. et al. Rapid cycling of reactive nitrogen in the marine boundary layer. Nature 532, 489-491 (2016).

29. Freyer, H. D., Kley, D., Volz-Thomas, A. \& Kobel, K. On the interaction of isotopic exchange processes with photochemical reactions in atmospheric oxides of nitrogen. J. Geophy. Res. Atmos. 98, 14791-14796 (1993).

30. Walters, W. W. \& Michalski, G. Theoretical calculation of nitrogen isotope equilibrium exchange fractionation factors for various $\mathrm{NOy}$ molecules. Geochim. Cosmochim. Acta 164, 284-297 (2015).

31. Liu, X. Y., Yin, Y. M. \& Song, W. Nitrogen isotope differences between major atmospheric NOy species: Implications for transformation and deposition processes. Environ. Sci. Technol. Lett. 7, 227-233 (2020).

32. Liu, X. Y. et al. Stable isotope analyses of precipitation nitrogen sources in Guiyang, Southwestern China. Environ. Pollut. 230, 486-494 (2017).

33. Dong, J. \& Zhang, J. Composite evaluation of replacing small generation units with large ones in the electricity sector in China. In 2008 International Conference on Risk Management \& Engineering Management, Beijing pp. 195-201. https://doi.org/10.1109/ICRMEM.2008.59 (2008).

34. Zhu, F. H. \& Zhao, G. H. Regulations and practice on flue gas denitrification for coal-fired power plants in China. Electricity 19, 53-56 (2008).

35. Zhang, Q., Ma, R., Xu, Y. N., Shi, J. R. \& Guan, F. Y. Comparison and analysis on flue gas denitrification technology in coal fired boiler retrofit. Adv. Mater. Res. 781, 2497-2501 (2013).

36. Felix, J. D., Elliott, E. M. \& Shaw, S. L. The isotopic composition of coal-fired power plant $\mathrm{NO}_{x}$ : the influence of emission controls and implications for global emission inventories. Environ. Sci. Technol. 46, 3528-3535 (2012)

37. Rohatgi, A. WebPlotDigitalizer: HTML5 based online tool to extract numerical data from plot images. Version 4.2. https://automeris.io/ WebPlotDigitizer/index.html (accessed on April 2019) (2019).

38. Barrie, L. A. Scavenging ratios, wet deposition, and in-cloud oxidation: an application to the oxides of sulphur and nitrogen. J. Geophys. Res. Atmos. 90, https://doi.org/10.1029/JD090iD03p05789 (1985).

39. Cheng, I. \& Zhang, L. M. Long-term air concentrations, wet deposition, and scavenging ratios of inorganic ions, $\mathrm{HNO} 3$ and $\mathrm{SO} 2$ and assessment of aerosol and precipitation acidity at canadian rural locations. Atmos. Chem. Phys. 17, $1-42$ (2017).

40. Yao, Z., Huo, H., Zhang, Q., Streets, D. G. \& He, K. Gaseous and particulate emissions from rural vehicles in China. Atmos. Environ. 45, 3055-3061 (2011).

41. Miller, D. J., Wojtal, P. K., Clark, S. C. \& Hastings, M. G. Vehicle $\mathrm{NO}_{x}$ emission plume isotopic signatures: spatial variability across the eastern United States. J. Geophys. Res. Atmos. 122, https://doi.org/10.1002/ 2016JD025877 (2017).

42. Yang, D. et al. High-resolution mapping of vehicle emissions of atmospheric pollutants based on large-scale, real-world traffic datasets. Atmos. Chem. Phys. 19, 8831-8843 (2019).

43. Parnell, A. C., Inger, R., Bearhop, S. \& Jackson, A. L. Source partitioning using stable isotopes: coping with too much variation. PLoS ONE 5, e9672 (2010).

44. Evans, J. S. B. T., Handley, S. J., Perham, N., Over, D. E. \& Thompson, V. A. Frequency versus probability formats in statistical word problems. Cognition. 77, 197-213 (2000).

45. Moore, J. W. \& Semmens, B. X. Incorporating uncertainty and prior information into stable isotope mixing models. Ecol. Lett. 11, 470-480 (2008). 
46. Liu, X. Y. et al. Nitrate is an important nitrogen source for Arctic tundra plants. Proc. Natl Acad. Sci. 115, 3398-3403 (2018).

47. Song, W. et al. Nitrogen isotope differences between atmospheric nitrate and corresponding nitrogen oxides: a new constraint using oxygen isotopes. Sci. Total Environ. 701, 134515 (2020).

\section{Acknowledgements}

This study was supported by the State Key Project of Research and Development Plan (2017YFC0210101, 2016YFA0600802), the National Natural Science Foundation of China (Nos. 41730855, 41522301, 42073005), the Outstanding Youth Funds of Tianjin (No. 17JCJQJC45400), the Coordinated Research Project of IAEA (F32008), Shenzhen Science and Technology Program (KQTD20180413181724653), and the 11th Recruitment Program of Global Experts (the Thousand Talents Plan) for Young Professionals granted by the central budget of China. We would like to gratefully thank all researchers and coauthors who reported and kindly provided us precious data of concentrations and isotopes of atmospheric $\mathrm{NO}_{x}, \mathrm{HNO}_{3}$, and $\mathrm{NO}_{3}{ }^{-}$.

\section{Author contributions}

X.-Y.L. designed the research. W.S., X.-Y.L., C.-C.H. conducted the research (data collections and analyses). W.S. and X.-Y.L. co-wrote the paper, G.-Y.C., X.-J.L., W.W.W. G.M. and C.-Q.L. commented on the manuscript.

\section{Competing interests}

The authors declare no competing interests.

\section{Additional information}

Supplementary information is available for this paper at https://doi.org/10.1038/s41467020-20356-0.

Correspondence and requests for materials should be addressed to X.-Y.L.

Peer review information Nature Communications thanks David Fowler, Shaoneng He, and Xuemei Wang for their contribution to the peer review of this work

Reprints and permission information is available at http://www.nature.com/reprints

Publisher's note Springer Nature remains neutral with regard to jurisdictional claims in published maps and institutional affiliations.

(c) (i) Open Access This article is licensed under a Creative Commons Attribution 4.0 International License, which permits use, sharing, adaptation, distribution and reproduction in any medium or format, as long as you give appropriate credit to the original author(s) and the source, provide a link to the Creative Commons license, and indicate if changes were made. The images or other third party material in this article are included in the article's Creative Commons license, unless indicated otherwise in a credit line to the material. If material is not included in the article's Creative Commons license and your intended use is not permitted by statutory regulation or exceeds the permitted use, you will need to obtain permission directly from the copyright holder. To view a copy of this license, visit http://creativecommons.org/ licenses/by/4.0/.

(c) The Author(s) 2021 